\title{
The Presence of Volatile Organic Compounds (VOCs) Indoors During the Heating Season: in situ Emission Study of a Frame-house
}

\author{
Csilla Patkó ${ }^{1}$, István Patkó ${ }^{2}$, Zoltán Pásztory ${ }^{1}$ \\ ${ }^{1}$ University of West Hungary, Innovation Center, 4 Bajcsy Zs. str. 9400 Sopron \\ 2 Obuda University, 6 Doberdo str. 1034 Budapest
}

\section{KEY WORDS}

Volatile organic compounds, indoor air quality, lightweight construction wooden house, low-energy buildings, emission of building materials.

\begin{abstract}
Due to the more stringent energy regulations the air-tightness and insulation of buildings is much higher than in old buildings. As a result of synthetic building materials and reduced air exchange rates indoor air quality is deteriorating significantly. In this study we examined the indoor air quality of a newly built, frame-house during the heating season. Formaldehyde (11-130 $\mathrm{mg} / \mathrm{m} 3)$, 3-carene $(133-300 \mu \mathrm{g} / \mathrm{m} 3)$ and alphapinene $(130-300 \mu \mathrm{g} / \mathrm{m} 3)$ values varied over a wide range depending on the indoor activities. We determined that further measurements are required on the subject during the summer period as well.
\end{abstract}

\section{Introduction}

We spend $80-90 \%$ of our lives inside buildings [1]. Environmental health researchers have been investigating intensively the indoor air quality of newly built homes, existing homes and converted homes [12] [13] [14]. Due to the more stringent energy regulations the air-tightness and insulation of buildings have grown exponentially. As a consequence of reduced air exchange rates air pollutants accumulate in the indoor air of the building. Several of the synthetic building materials, the paints and solvents used inside, the interior design materials (carpet, upholstery, OSB, chipboard, etc.) and the human activities (cooking, smoking, etc.) are considered as a source of harmful substance [2] [3] [4]. These harmful substances include volatile organic compounds (VOCs) and formaldehyde. On the turn of the millennium environmental health researchers confirmed the negative impact of indoor air quality on the residents' health [5]. The slow emission of volatile substances does not only impact the human body, but also influences the lifetime of the materials built in [6]. There is no established scheme for the evaluation of the used artificial ventilation systems, and the requirements for the emission rates of new building materials are also incomplete [7] [8]. During the design phase it is important to take into consideration the VOC emission of building materials. Based on these it is necessary to select materials which do not pose a threat to health. It is also important to mention the tested fact that indoor VOC concentration is higher than concentrations measured outdoors [10] [11]. This fact was revealed by the European Exposure Study (EXPOLIS) [15] [16]. It follows that 
the presence of indoor pollutants has a greater impact on public health than outdoor pollutants as people spend $80-90 \%$ of their day inside buildings. In several studies the seasonal cycle of indoor pollutants has been studied. It was found that there are differences between the results of winter and summer VOC measurements [17].

This study aims to present the changes in formaldehyde and VOC concentrations measured in the indoor air of a low-energy, frame- house in the heating season. The residents did not move in the house after the completion of the construction, only experimental measurements were conducted. Part of our experiment was to observe how the results of each measurement were influenced by the interior design finishing (installation of interior doors, skirting of wood covers, etc.).

\section{Volatile Organic Compounds 2.1 Volatile organic compounds and their sources, rel- evant regulations}

VOCs consist of several, different organic groups. The World Health Organisation (WHO) defined these groups in 1989: (1) very volatile organic compounds (VVOCs) with a boiling point between $0^{\circ} \mathrm{C}$ and $50-100^{\circ} \mathrm{C}$, (2) volatile organic compounds (VOCs), boiling point: between $50-100^{\circ} \mathrm{C}$ and $240-260^{\circ} \mathrm{C}$, (3) semi volatile organic compounds (SVOCs), boiling point: above $240-260^{\circ} \mathrm{C}$ [9]. The most frequently monitored VOCs are benzene, toluene, ethylbenzene and xylenes (BTEX) as well as formaldehyde [18]. These substances are considered primarily harmful to health. Their main sources are building materials, cleaning supplies, furniture, paints, adhesives, coatings and textiles [19] [20] [21]. Other factors affecting their concentration are the urban areas, the attached garage, the gas appliances installed in the house as well as indoor smoking [22] [23] [24]. Other frequently occurring organic materials include terpenes, C1 - C4 alkali benzenes, alkanes, aliphatic aldehydes and some cycloalkanes [50]. Only a few countries have regulations and specifications to assess indoor air quality and to classify substances based on their rate of emission. In 2000 the EU directive defined benzene limit at $5 \mathrm{\mu g} / \mathrm{m}^{3}$ [25]. The European directive 89/106/EEC required that buildings must be constructed in a way that the emissions emerging indoors shall not pose a threat to the health of the occupants staying indoors [26]. Several countries in Europe have standards to classify low-emission substances (AgBB, M1 Classification, EMICODE, Blue Angel, Ecolabel, Nordic Swan, BUMA, PANDORA, etc.). [27]

\subsection{Health effects of volatile organic compounds}

Several studies assume that the possible root cause of Sick Building Syndrome is VOC concentration in indoor air. The main symptoms are headache, nausea, eye and nasal irritation, asthmatic symptoms [28] [29]. Furthermore, it is assumed that more toxic or potentially toxic VOCs cause health problems in the case of new buildings [30] [31]. The symptoms are observed mainly in the upper respiratory tract, in the sensory systems and they may to a large extent cause the development of allergy or asthma [32] [33] [34] [35]. In 2004 the Agency for Research on Cancer (IARC) included formaldehyde and benzene in the group of carcinogenic substances for humans as primary pathogens [36].

\section{Overview of Case Studies from Professional Literature}

Several studies have examined and measured the concentration of pollutants in indoor air in a laboratory environment. However, site measurements which link the pollutants to their potential sources are quite deficient [37] [38].

Study [38] determines in Europe - with on-site measurements - the potential sources of VOCs in residential buildings and public institutions. They mainly tested carbonyl compounds (aldehydes, ketones, acetaldehydes, etc.), BTEX (benzene, toluene, ethylbenzene, and xylenes) and terpenes. The measurements were conducted between 2007 and 2008 in five European cities (Athens, Nicosia, Dublin, Copenhagen, Milan), in 4 buildings per city during both summer and winter periods. The buildings studied were chosen to ensure they were not older than 2 years and their location in the city were taken into account. The measurements were conducted with passive collectors and in some cases the FLEC (Field and Laboratory Emission Cell) gauge was used. The measurements were conducted according to ISO 16000/3 and 16000/6. In addition, questionnaires were used to determine the relevant data regarding the circumstances of the measurements. The questionnaire consisted of three parts: (1) general data of the measurements, 
(2) the type and location of the tested building and its architectural design, (3) the use of the tested building. After evaluating the measurement results it was found that (1) the most commonly used building materials are water-based paints, plaster and plywood, (2) carbon compounds, ketones and aromatic hydrocarbons were measured in the highest amount, (3) the concentrations measured during the winter season were higher than in the summer probably due to the strong air tightness of the building, (4) the presence of BTEX and terpenes showed a decreasing trend over time [38].

In study [39] the indoor air quality of 107 newly built, South-Korean apartments was tested in conditions prior to the move-in, in urban and rural environments. The apartments have been executed six months prior to the measurement. Their main building materials: reinforced concrete, parquet, PVC, plywood. Naphthalene, aromatic hydrocarbons, ketones, terpenes and aldehydes concentrations were outstanding. The emission rates of the substances were determined from the values obtained and with the help of the Indoor and Mass Balance Model. In addition, based on the Principal Component Analysis (PCA) they determined the type of building materials and coverings which are the sources of harmful substances. This method had been applied by Guo in his studies [40] [41] on an experimental basis. Four main sources were found: wood panels, PVC, adhesives and paints.

In study [42] it was emphasized that in Korea most newly built apartments are known to cause Sick Building Syndromes (SBS). Therefore the Indoor Air Quality Management Act [43] specified the maximum concentration of formaldehyde and five VOC substances in the indoor air of newly built homes. The study examines how efficiently VOC concentration values may be reduced through ventilation and the use of air cleaning products. Formaldehyde, TVOC and toluene concentrations were extremely high in relation to other international values. Formaldehyde is supposed to come from wood furniture and floors. The source of toluene is PVC wallpaper which was applied not only on the walls but also on the ceilings. Contrary to western habits textiles and paints are not used in Korean homes, presumably that is the reason why there were no significant concentrations of benzene and xylenes.

\section{The Methodology of Measurements 4.1 The introduction of the studied building}

The sampling was performed in a newly built, low-energy, frame-house.

The turnkey construction of the building was completed in the summer of 2012. It has an area of $120 \mathrm{~m}^{2}$, a ground floor and an attic room. Downstairs there are a hall, a living room + a kitchen, a room and a bathroom. From the living room there is a staircase leading up to the gallery, which opens into a room in the attic.

The structure of the building consists of wooden frames and wooden panels with Isocell insulation, which is rendered from the outside and covered with gypsum fibre panels inside (Table 1). The interior walls are covered with solid wood panels. The house is heated with circulating hot air combined with an airing system. The heat is derived from solar panels and stored in seasonal thermal storage system. In addition, the ground floor heating is supported by electric under-floor heating in winter. The parameters of the rooms included in the sampling are given in Table 2.

Table 1: Outside wall layers (outside to inside)

\begin{tabular}{|c|c|c|c|c|}
\hline No. & Thickness & & Description & $\begin{array}{l}\text { Thermal } \\
\text { conductivity } \\
\mathrm{W} / \mathrm{mK}\end{array}$ \\
\hline 1 & 5 & $\mathrm{~mm}$ & Breathable render & 0.6 \\
\hline 2 & 60 & $\mathrm{~mm}$ & $\begin{array}{l}\text { Fiber Insulation } \\
\text { Panel THD NF } 230\end{array}$ & 0.05 \\
\hline \multirow[t]{2}{*}{3} & 160 & $\mathrm{~mm}$ & $\begin{array}{l}\text { KVH 60x160 mm } \\
\text { spruce, truss frame }\end{array}$ & 0.1 \\
\hline & & & $\begin{array}{l}\text { with } 160 \text { mm ISO- } \\
\text { CELL in between }\end{array}$ & 0.039 \\
\hline 4 & 12 & $\mathrm{~mm}$ & MFP & 0.13 \\
\hline \multirow[t]{2}{*}{5} & 160 & $\mathrm{~mm}$ & $\begin{array}{l}\text { KVH } 60 \times 160 \mathrm{~mm} \\
\text { spruce, truss frame }\end{array}$ & 0.1 \\
\hline & & & $\begin{array}{l}\text { with } 160 \text { mm ISO- } \\
\text { CELL in between }\end{array}$ & 0.039 \\
\hline 6 & 15 & $\mathrm{~mm}$ & $\begin{array}{l}\text { H15 gypsum fibre } \\
\text { board }\end{array}$ & 0.22 \\
\hline 7 & 0.25 & $\mathrm{~mm}$ & $\begin{array}{l}\text { ÖKO-NATUR va- } \\
\text { pour-stop paper }\end{array}$ & \\
\hline 8 & 30 & $\mathrm{~mm}$ & $\begin{array}{l}\text { Planed and dried } \\
\text { spruce, batten } \\
\text { framework }\end{array}$ & - \\
\hline 9 & 12.5 & $\mathrm{~mm}$ & $\begin{array}{l}\text { impregnated } \\
\text { plasterboard }\end{array}$ & 0.24 \\
\hline
\end{tabular}


Table 2: Parameters of the rooms

\begin{tabular}{|c|c|c|c|c|c|c|}
\hline \multicolumn{2}{|r|}{ Room } & \multirow{2}{*}{$\begin{array}{l}\text { Structure } \\
\text { Floor }\end{array}$} & \multirow{2}{*}{$\begin{array}{l}\text { Cover } \\
\text { Stone }\end{array}$} & \multicolumn{2}{|l|}{ Area } & \multirow{2}{*}{$\begin{array}{l}\text { Comment } \\
\text { unfurnished }\end{array}$} \\
\hline 1 & Living room & & & 25.4 & $\mathrm{~m}^{2}$ & \\
\hline & & Wall & Gypsum fibre /Wood & $50.0 / 30.0$ & $m^{2}$ & \\
\hline & & Ceiling & Wood & 48.5 & $m^{2}$ & \\
\hline \multirow[t]{3}{*}{2} & Room & Floor & Stone & 12.0 & $m^{2}$ & unfurnished \\
\hline & & Wall & Gypsum fibre/Wood & $17.0 / 16.0$ & $m^{2}$ & \\
\hline & & Ceiling & Cement rendering & 12 & $m^{2}$ & \\
\hline \multirow[t]{3}{*}{3} & Bathroom & Floor & Stone & 5.04 & $m^{2}$ & unfurnished \\
\hline & & Wall & Wood & 24.1 & $m^{2}$ & \\
\hline & & Ceiling & Cement rendering & 5.04 & $m^{2}$ & \\
\hline
\end{tabular}

\subsection{On-site measurement}

Sampling was performed in the building described in Section 4.1 and the samples were analysed by the laboratory of Wessling Hungary Ltd. An active sampling device was used on the site. During the sampling, in order to facilitate the accuracy of the laboratory tests the physical characteristics of indoor air had been set 24 hours before the sampling. Thus the sampling was performed in a stationary state. The air exchange rate was $2.51 / \mathrm{h}$, which means that during the measurement the doors and windows were closed [51].

Two sampling tubes were connected to the active measuring device used in the sampling. One sampling tube was a $200 \mathrm{mg}$ Tenax TA stainless steel tube, $90 \mathrm{~mm}$ long, for sampling the VOCs.

\section{Suction duration: $60 \mathrm{~min}$ \\ Suction rate: $100 \mathrm{ml} / \mathrm{min}$ \\ Suctioned air volume: $6000 \mathrm{ml}$}

The other 150/300 $\mathrm{ml}$ tube filled with dinitrophenylhydrazine formaldehyde-impregnated silica gel for sampling formaldehyde:

\section{Suction duration: $240 \mathrm{~min}$}

\section{Suction rate: $200 \mathrm{ml} / \mathrm{min}$}

\section{Suctioned air volume: $48000 \mathrm{ml}$}

\section{Evaluation of Measurement Results}

When we determined the VOC content of the samples taken from the indoor air we measured the concentrations of 180 components according to standards ISO 16000-6:2004 and ISO 16000-3:2001. In Table 3 we included the measured concentrations of those VOC components out of the 180 measurement results whose values were significantly greater than the detection limit and are present in each room. Presumably, these are the materials which determine the quality of indoor air in the building.

\subsection{The results of the measurements and their conditions Measurement 1:}

After the construction of the building was completed, the first measurement was taken before the heating was started. At this stage the inside doors had not been installed yet. The measurement was taken in the living room. Most of the measured values stayed well below $50 \mu \mathrm{g} / \mathrm{m}^{3}$, except for the values of limonene $\left(64.7 \mu \mathrm{g} / \mathrm{m}^{3}\right)$, hexanal $\left(48.9 \mu \mathrm{g} / \mathrm{m}^{3}\right)$, alpha-pinene $\left(297 \mathrm{\mu g} / \mathrm{m}^{3}\right)$ and 3-carene $(300 \mu \mathrm{g} /$ $\left.\mathrm{m}^{3}\right)$, which differ substantially from the other values. Sarigiannis [50] (in the 2011 study) determined as the average value for Central Europe $17.2 \mathrm{\mu g} / \mathrm{m}^{3}$ for limonene, $3.11 \mu \mathrm{g} / \mathrm{m}^{3}$ for benzene, $29.8 \mu \mathrm{g} / \mathrm{m}^{3}$ for formaldehyde and $12.9 \mu \mathrm{g} / \mathrm{m}^{3}$ for alpha-pinene. The benzene $\left(3.11 \mu \mathrm{g} / \mathrm{m}^{3}\right)$ and formaldehyde $\left(34 \mathrm{\mu g} / \mathrm{m}^{3}\right)$ concentration values measured in this study correspond to the average values reported, while the measured values of limonene and alpha-pinene are significantly higher than the average values given [1].

\section{Measurement 2:}

The interior doors had not been installed, but the air heater had been turned on. The samples were taken in the three most characteristic points of the house. The living room has the largest airspace $\left(123 \mathrm{~m}^{3}\right)$, the $2 . r o o m$ is an average sized room $\left(33 \mathrm{~m}^{3}\right)$, which is not directly connected to the living room, the room in the attic is $45 \mathrm{~m}^{3}$. We also sampled the outside air. In the outside air the value of benzene was higher than the concentration values measured indoors (Table 4). In the samples taken indoors the 
Table 3: Measured concentration of VOC components

\begin{tabular}{|c|c|c|c|c|c|c|c|c|c|c|c|c|c|c|}
\hline & Unit & $\begin{array}{c}\text { Measurement } \\
1\end{array}$ & $\begin{array}{c}\text { Measurement } \\
2\end{array}$ & & $\begin{array}{c}\text { Measurement } \\
3\end{array}$ & & $\begin{array}{c}\text { Measurement } \\
4\end{array}$ & & & & & & & \\
\hline $\begin{array}{l}\text { Date of } \\
\text { Measurement }\end{array}$ & & $10 / 12 / 2012$ & $17 / 01 / 2013$ & & $14 / 02 / 2013$ & & 07/03/2013 & & & & & & & \\
\hline Temperature & ${ }^{\circ} \mathrm{C}$ & 18 & 18 & & 18 & & 21 & & & & & & & \\
\hline $\begin{array}{l}\text { Relative } \\
\text { Humidity }\end{array}$ & $\%$ & 41 & 37 & & 37 & & 40 & & & & & & & \\
\hline Compound name & & Indoors & $\begin{array}{l}\text { 1. Living } \\
\text { room }\end{array}$ & 2. Room & 3. Attic & Average & $\begin{array}{l}\text { 1. Living } \\
\text { room }\end{array}$ & 2. Room & 3. Attic & Average & $\begin{array}{l}\text { 1. Living } \\
\text { room }\end{array}$ & 2. Room & 3. Attic & Average \\
\hline Formaldehyde & $\mu \mathrm{g} / \mathrm{m}^{3}$ & 34 & 11 & 4 & 10 & 8.33 & 130 & 10 & 23 & 54.33 & 32 & 21 & 49 & 34.00 \\
\hline Benzene & $\mu \mathrm{g} / \mathrm{m}^{3}$ & 3.11 & 2.79 & 2 & 2.16 & 2.32 & 1.6 & 1.6 & 1.6 & 1.6 & 1.6 & 1.66 & 1.6 & 0.55 \\
\hline Toluene & $\mu \mathrm{g} / \mathrm{m}^{3}$ & 11.6 & 4.92 & 4.78 & 5.09 & 4.93 & 5.16 & 4.74 & 6.13 & 5.34 & 4.97 & 6.85 & 19.7 & 10.51 \\
\hline Ethyl benzene & $\mu \mathrm{g} / \mathrm{m}^{3}$ & 4.8 & 1.96 & 1.81 & 1.86 & 1.88 & 1.66 & 1.27 & 1.46 & 1.46 & 4.14 & 4.38 & 33 & 13.84 \\
\hline $\begin{array}{l}\text { 1.3-Xylene and } \\
\text { 1.4-Xylene }\end{array}$ & $\mu \mathrm{g} / \mathrm{m}^{3}$ & 20.8 & 8.59 & 7.57 & 8.23 & 8.13 & 6.72 & 5.36 & 5.31 & 5.80 & 11.6 & 12.5 & 104 & 42.70 \\
\hline Styrene & $\mu \mathrm{g} / \mathrm{m}^{3}$ & 3.06 & 0.96 & 1.2 & 1.32 & 1.16 & 0.8 & 0.8 & 0.8 & 0.8 & 3.52 & 4.98 & 0.8 & 2.83 \\
\hline n-Undecane & $\mu \mathrm{g} / \mathrm{m}^{3}$ & 25.4 & 10.8 & 18.9 & 7.07 & 12.26 & 14.8 & 8.73 & 7.91 & 10.48 & 21.1 & 13.7 & 18.8 & 17.87 \\
\hline n-Dodecane & $\mu \mathrm{g} / \mathrm{m}^{3}$ & 6.96 & 0.9 & 34.7 & 0.9 & 12.17 & 17.4 & 2.48 & 4.17 & 8.02 & 10.3 & 9.72 & 6.47 & 8.83 \\
\hline n-Tridecane & $\mu \mathrm{g} / \mathrm{m}^{3}$ & 22.9 & 19 & 15.7 & 13.3 & 16.00 & 15.2 & 7.08 & 5.48 & 9.25 & 41 & 19.5 & 21.6 & 27.37 \\
\hline n-Tetradecane & $\mu \mathrm{g} / \mathrm{m}^{3}$ & 31.3 & 39.4 & 28.1 & 26.8 & 31.43 & 22.3 & 12 & 8.65 & 14.32 & 43.3 & 33.2 & 30.9 & 35.80 \\
\hline n-Pentadecane & $\mu \mathrm{g} / \mathrm{m}^{3}$ & 8.94 & 14.7 & 11.9 & 10.4 & 12.33 & 8.53 & 4.56 & 3.93 & 5.67 & 15.4 & 13.1 & 11.6 & 13.37 \\
\hline n-Hexadecane & $\mu \mathrm{g} / \mathrm{m}^{3}$ & 2.82 & 5.41 & 5.48 & 4.27 & 5.05 & 3.42 & 1.98 & 2.1 & 2.50 & 8.12 & 5.8 & 5.4 & 6.44 \\
\hline 3-Carene & $\mu \mathrm{g} / \mathrm{m}^{3}$ & 300 & 133 & 97.3 & 109 & 113.10 & 85.8 & 64.4 & 233 & 127.73 & 300 & 244 & 274 & 272.67 \\
\hline alpha-pinene & $\mu \mathrm{g} / \mathrm{m}^{3}$ & 297 & 170 & 122 & 157 & 149.67 & 162 & 119 & 300 & 193.67 & 300 & 300 & 300 & 300.00 \\
\hline beta-Pinene (b) & $\mu \mathrm{g} / \mathrm{m}^{3}$ & 30 & 15.2 & 11.8 & 15.3 & 14.10 & 16.9 & 9.33 & 33.1 & 19.78 & 55.9 & 52.9 & 47.8 & 52.20 \\
\hline Limonene & $\mu \mathrm{g} / \mathrm{m}^{3}$ & 64.7 & 21 & 16.1 & 17.5 & 18.20 & 15.8 & 10.7 & 23 & 16.50 & 59.7 & 51.9 & 46.3 & 52.63 \\
\hline Pentanal & $\mu \mathrm{g} / \mathrm{m}^{3}$ & 14.4 & 6.83 & 5.53 & 5.49 & 5.95 & 0.8 & 0.8 & 0.8 & 0.8 & 17.6 & 22.7 & 0.8 & 13.70 \\
\hline Hexanal & $\mu \mathrm{g} / \mathrm{m}^{3}$ & 48.9 & 23.8 & 19 & 21.3 & 21.37 & 16.4 & 9.88 & 20.7 & 15.66 & 79 & 57.8 & 65.9 & 67.57 \\
\hline Benzaldehyde & $\mu \mathrm{g} / \mathrm{m}^{3}$ & 7.27 & 0.8 & 3.87 & 0.8 & 3.87 & 3.37 & 1.67 & 5.35 & 3.46 & 9.87 & 10.4 & 16.8 & 12.36 \\
\hline $\begin{array}{l}\text { 2-Methoxy- } \\
\text { 1-ethylmethyl } \\
\text { acetate }\end{array}$ & $\mu \mathrm{g} / \mathrm{m}^{3}$ & 28.8 & 17 & 14.3 & 14 & 15.10 & 24.5 & 15.3 & 12.8 & 17.53 & 110 & 123 & 78.2 & 103.73 \\
\hline
\end{tabular}

concentration values of 3 -carene $\left(133 \mu \mathrm{g} / \mathrm{m}^{3}\right)$ and alpha-pinene $\left(170 \mu \mathrm{g} / \mathrm{m}^{3}\right)$ decreased considerably compared to the previous measurement as a result of the air heating system. Formaldehyde $\left(11 \mu \mathrm{g} / \mathrm{m}^{3}\right)$ and benzene values further decreased $\left(2.79 \mu \mathrm{g} / \mathrm{m}^{3}\right)$.

\section{Measurement 3:}

The interior doors were installed, except for the attic room, so for this measurement the 3rd sample was taken from the bathroom. Due to the economical operation of the house the air heating had to be turned on much less frequently to achieve an average temperature of $18^{\circ} \mathrm{C}$. However, the effect of interior finishing is significant reflected in the value of formaldehyde. Because of cutting the built-in timber to size the formaldehyde value is $130 \mu \mathrm{g} / \mathrm{m} 3$, which exceeds the $100 \mu \mathrm{g} / \mathrm{m} 3$ specified by WHO [45]. The significant increase in the value of the acetic acid $\left(138 \mathrm{\mu g} / \mathrm{m}^{3}\right)$ may be derived from the silicone grout material. Benzene decreased below the limit of detection. The maximum value of 3 -carene is $(233 \mu \mathrm{g} /$ $\left.\mathrm{m}^{3}\right)$. Alpha-pinene $\left(300 \mu \mathrm{g} / \mathrm{m}^{3}\right)$ also increased significantly compared to previous measurements.

\section{Measurement 4:}

As an experiment, we increased the indoor air temperature to $21^{\circ} \mathrm{C}$ by turning on the air heating sytem and under-floor heating. This was an important part of the experiment since this temperature corresponds to the average temperature in the winter period [47]. It was at this time that the highest measured concentrations occurred: 3-carene $(300 \mu \mathrm{g} /$ $\left.\mathrm{m}^{3}\right)$, alpha-pinene $\left(300 \mu \mathrm{g} / \mathrm{m}^{3}\right)$ is significantly higher than the average, hexanal $\left(79 \mu \mathrm{g} / \mathrm{m}^{3}\right)$, and acetate 
$\left(110 \mu \mathrm{g} / \mathrm{m}^{3}\right)$ are moderately different values. However, xylene value in the bathroom increased significantly $\left(104 \mu \mathrm{g} / \mathrm{m}^{3}\right)$. Formaldehyde, beta-pinene and limonene approach the value of $50 \mu \mathrm{g} / \mathrm{m}^{3}$. Formaldehyde decreased below $50 \mu \mathrm{g} / \mathrm{m}^{3}$. Benzene $(1.66$ $\mu \mathrm{g} / \mathrm{m}^{3}$ ) still did not come close to the average value of $5 \mu \mathrm{g} / \mathrm{m}^{3}$.

Table 4: Measurement 2 - Concentration of VOC substances indoors and outdoors.

\begin{tabular}{|c|c|c|c|c|c|}
\hline Temperature & ${ }^{\circ} \mathrm{C}$ & \multicolumn{3}{|l|}{18} & 1 \\
\hline \multirow{2}{*}{$\begin{array}{l}\text { Relative } \\
\text { Humidity }\end{array}$} & $\%$ & \multicolumn{3}{|l|}{37} & 86 \\
\hline & & $\begin{array}{l}\text { 1. Living } \\
\text { room }\end{array}$ & 2. Room & 3. Attic & 4. Outdoor \\
\hline $\begin{array}{l}\text { Formalde- } \\
\text { hyde }\end{array}$ & $\mu \mathrm{g} / \mathrm{m}^{3}$ & 11 & 4 & 10 & 4 \\
\hline Benzene & $\mu \mathrm{g} / \mathrm{m}^{3}$ & 2,79 & 2 & 2,16 & 3,5 \\
\hline Toluene & $\mu \mathrm{g} / \mathrm{m}^{3}$ & 4,92 & 4,78 & 5,09 & 2,9 \\
\hline $\begin{array}{l}\text { 1.3-Xyle- } \\
\text { ne and } \\
\text { 1.4-Xylene }\end{array}$ & $\mu \mathrm{g} / \mathrm{m}^{3}$ & 8,59 & 7,57 & 8,23 & 1,1 \\
\hline $\begin{array}{l}\text { Alpha-pi- } \\
\text { nene }\end{array}$ & $\mu \mathrm{g} / \mathrm{m}^{3}$ & 170 & 122 & 157 & 2,6 \\
\hline Acetic acid & $\mu \mathrm{g} / \mathrm{m}^{3}$ & 17,6 & 26,9 & 26,9 & 13,6 \\
\hline
\end{tabular}

By summing the measured concentrations of volatile organic compounds listed in Table 4, we get the TVOC values. These values are plotted in Fig. 1. The graph clearly shows that TVOC concentrations are reduced when the air heating system was turned on. This can be explained by the fact that artificial indoor air movement created a homogeneous concentration distribution. During the fourth measurement when the temperature was heated up to $21^{\circ} \mathrm{C}$ the under-floor heating was switched on as well. We assume that the under-floor heating may result in an increased concentration of TVOC. This assumption of ours seems to be confirmed by study [52].

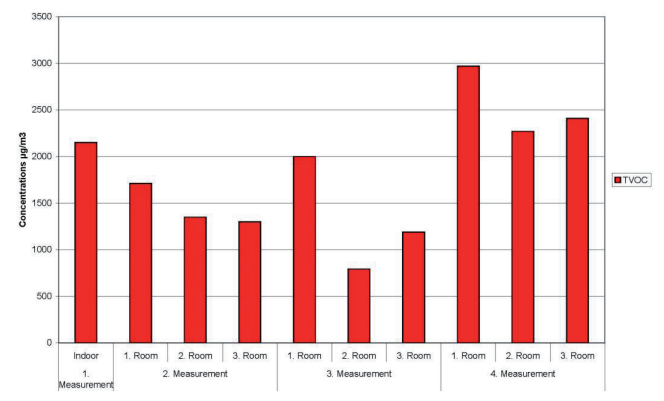

Fig. 1: Change in TVOC values in each room

\subsection{Lowest Concentration of Interest analysis}

German laws specify that the VOC emission from building materials shall be reduced in the long term so much that it should not pose a risk to the health of the occupants of the building. The workgroup of AgBB (Ausschuss gesundheitlichen Bewertung von zur BAUPRODUKTE) created a list of VOCs determining the quality of indoor air and at the same time gave the concentration limits of VOCs impairing air quality [48] [49]. If the concentration of the tested VOC substance is below the specified limit, it does not pose a health risk to the occupants of the building.

The degree of health risk is expressed by a ratio; the value of the measured concentration is divided by the limit value according to $\mathrm{AgBB}$. If this ratio is less than one, the tested substance does not pose a health risk. If the ratio is more than one, then the value of the health risk caused by the substance is proportional to the value of the ratio. Table 5 contains the VOCs which we measured, the average of the measured concentrations, the limit of the concentration $(\mathrm{LCl})$ and their quotient.

Table 5 shows that none of the VOCs tested by us pose a health risk to the occupants in the building. However, it may be established that the health risk of benzene (0.622) stands out from the tested substances.

\section{Final Conclusion}

The following conclusions may be drawn from the evaluation of the series of measurements of VOC concentrations taken during winter period:

1.The conditions during the measurements significantly influenced the concentration of certain values (formaldehyde, 3-carene, alpha-pinene).

2. The significant increase in formaldehyde, 3-carene, alpha-pinene shows that their main source is wood-based building materials.

3. The increase in indoor air temperature may cause the increase in concentrations.

4. None of the concentrations of the tested substances reached the extent of adverse health effects [49].

\section{Further measurements are necessary in summer.}

\section{Summary}

TWe tested indoor air quality in the interior space of a frame-house constructed in the area of the University of West Hungary (see section 4.1). Before our study was designed and implemented we carried 
Table 5: The health risk of the measured substances

\begin{tabular}{|c|c|c|c|c|c|c|}
\hline $\begin{array}{l}\text { Compound } \\
\text { name }\end{array}$ & $\begin{array}{l}\text { Measurement } \\
1-\mu g / m^{3}\end{array}$ & $\begin{array}{l}\text { Measurement } \\
2-\text { Average } \\
\mathrm{\mu g} / \mathrm{m}^{3}\end{array}$ & $\begin{array}{l}\text { Measurement } \\
3 \text {-Average } \\
\mathrm{\mu g} / \mathrm{m}^{3}\end{array}$ & $\begin{array}{l}\text { Measurement } \\
4 \text {-Average } \\
\mu \mathrm{g} / \mathrm{m}^{3}\end{array}$ & LCI $\left[\mu g / m^{3}\right]$ & $\begin{array}{l}\text { Largest } \\
\text { measured } \\
\text { concentration } \\
\text { /LCI }\end{array}$ \\
\hline Benzene & 3.11 & 2.32 & 0.8 & 0.55 & 5 & 0.622 \\
\hline Toluene & 11.6 & 4.93 & 5.34 & 10.51 & 1900 & 0.00061 \\
\hline Ethyl benzene & 4.8 & 1.88 & 1.46 & 13.84 & 4400 & 0.00031 \\
\hline $\begin{array}{l}\text { 1.3-Xylene and } \\
\text { 1.4-Xylene }\end{array}$ & 20.8 & 8.13 & 5.80 & 42.70 & 2200 & 0.019 \\
\hline Styrene & 3.06 & 1.16 & 0.00 & 2.83 & 860 & 0.00035 \\
\hline 3-Carene & 300 & 113.10 & 127.73 & 272.67 & 1500 & 0.2 \\
\hline alpha-pinene & 297 & 149.67 & 193.67 & 300.00 & 1500 & 0.2 \\
\hline $\begin{array}{l}\text { beta-Pinene } \\
\text { (b) }\end{array}$ & 30 & 14.10 & 19.78 & 52.20 & 1500 & 0.0348 \\
\hline Limonene & 64.7 & 18.20 & 16.50 & 52.63 & 1500 & 0.0431 \\
\hline Pentanal & 14.4 & 5.95 & 0.00 & 13.70 & 890 & 0.0161 \\
\hline Hexanal & 48.9 & 21.37 & 15.66 & 67.57 & 890 & 0.0759 \\
\hline
\end{tabular}

out detailed literature search on the subject. We explored the methods used in air quality testing. We compared the results obtained and we drew conclusions from them. Taking these into account we designed the on-site sampling and the laboratory measurements.

On the basis of the laboratory results we determined the health risks of the air to humans in the building tested. We compared the pollutant content of the indoor air space of our building with the measured values of European cities taken from the literature. We determined that further measurements are required on the subject during the summer period as well.

\section{Acknowledge}

This study was supported by the Environmental Analytical Laboratory of Wessling Hungary Ltd. and its employees.

This study was supported by the Environment conscious energy efficient building TAMOP4.2.2.A-11/1/KONV-2012-0068 project sponsored by the EU and European Social Foundation.

\section{References}

[1] Sarigiannis, D.A., Karakitsios, S.P., Gotti, A., Liakos, I.L., Katsoyiannis, A., 2011. Exposure to major volatile organic compounds and carbonyls in European indoor environments and associated health risk. Environment International 37
(4), $743-765$.

[2] Schmidt-Etkins D.(1994) Walls and IAQ: Health Impacts. Prevention and Mitigation. Indoor Air Quality, Update. Cutter Information Corp. Arlington, U.S.A.

[3] Wallace, L.A., Pellizzari, E., Leaderer, B., Zelon, H., Sheldon, L., (1987). Emissions of volatile organic compounds from building materials and consumer products. Atmospheric Environment 21, 385-393

[4] Sack, T.M., Steele, D.H., (1992). A survey of household products for volatile organic compounds. Atmospheric Environment 26A, 1063-1070.

[5] Wallace, L.A. (2001) Human exposure to volatile organic pollutants: implications for indoor air studies. Annual Review of Energy and the Environment 26, 269-301.

[6] Jantunen, M.J., Hanninen, O., Katsouyanni, K., Knoppel, H., Kuenzli, N., Lebret, E., Maroni, M., Saarela, K., Sram, R., Zmirou, D., (1998) Air pollution exposure in European cities: The "expolis" study. Journal of Exposure Analysis and Environmental Epidemiology 8 (4), 495-518.

[7] Yu, C., Crump, D., (1998) Review of the Emission of VOCs from Polymeric Materials used in Buildings. Building and Environment, Vol 33, No. 6, pp. 357-374, 1998

[8] Willem, H., Singer, B.C., (2010) Chemical Emissions of Residential Materials and Products: Review of Available Information. Environmental Energy Technologies Division. Ernest Orlando Lawrence Berkeley National Laboratory. LBNL - 3938E

[9] World Health Organisation (WHO), (1989) Indoor Air Quality: Organic Pollutants, EURO Reports and Studies No III, 
World Health Organisation, Copenhagen, Denmark

[10] De Bortoli M., Kniippel H., Pecchio E., Peil A., Rogora L., Schauenburg H., Schlitt H. and Vissers H. (1986) Concentrations of selected organic pollutants in indoor and outdoor air in nothern Italy. Environ. Int. 12, 343.

[11] Yocom J. (1982) Indoor-outdoor air quality relationships. I. Air Polk Control Assoc. 32, 500.

[12] Järnström, H., Saarela, K., Kalliokoski, P., Pasanen, A.-L., (2006). Reference values for indoor air pollution concentrations in new residential buildings in Finland. Atmos. Environ. 40, 7178-7191.

[13] Järnström, H., Saarela, K., Kalliokoski, P., Pasanen, A.-L., (2007). Reference values for structure emissions measured on site in new residential buildings in Finland. Atmos. Environ. 41, 2290-2302.

[14] Park, J.S., Ikeda, K., (2006). Variations of formaldehyde and VOC levels during 3 years in new and older homes. Indoor Air 16, 129-135.

[15] Edwards, R., Jurvelin, J., Saarela, K., Jantunen, M., 2001. VOC concentrations measured in personal samples and residential indoor, outdoor and workplace microenvironments in EXPOLIS- Helsinki, Finland. Atmospheric Environment 35, 4531-4543.

[16] Saarela, K., Tirkkonen, T., Laine-Ylijoki, J., Jurvelin, J., Nieuwenhuijsen, M.J., Jantunen, M., (2003). Exposure of population and microenvironmental distributions of volatile organic compound concentrations in the EXPOLIS study. Atmospheric Environment 37, 5563-5575.

[17] U. Schlinka, M. Rehwagen, M. Damm, M. Richter, M. Borte, O. Herbarth (2004) Seasonal cycle of indoor-VOCs: comparison of apartments and cities. Atmospheric Environment 38 (2004) 1181-1190

[18] Zalel, A., Yuval, Broday, D.M., (2008). Revealing source signatures in ambient BTEX concentrations. Environmental Pollution 156, 553 - 562.

[19] Samfield M. M. (1992) Indoor air quality data base for organic compounds, 'EPA-600/13 (1992).

[20] Sterling D. A. (1985) Indoor Air and Human Healths. Volatile Organic Compounds in Indoor Air: An Overview of Sources, Concentrations, and Health Effects (edited by Gammage R. B.. Kave S. B. and Jacobs V. A.). D. 387.

[21] Wallace, L.A., (2001). Human exposure to volatile organic pollutants: implications for indoor air studies. Annual Review of Energy and the Environment 26, 269-301.

[22] Dodson, R.E., Levy, J.I., Spengler, J.D., Shine, J.P., Bennett, D.H., (2008). Influence of basements, garages, and common hallways on indoor residential volatile organic compound concentrations. Atmospheric Environment 42, 1569-1581.

[23] Kwon, K.D., Jo, W.K., Lim, H.J., Jeong, W.S., (2007). Characterization of emissions composition for selected household products available in Korea. Journal of Hazardous Materials 148, 192-198.

[24] Edwards, R.D., Schweizer, C., Llacqu, V., Lai, H.K., Jantunen, M., Bayer-Oglesby, L., Kunzli, N., (2006). Time-activity relationships to VOC personal exposure factors. Atmospheric Environment 40, 5685-5700.

[25] Legislation, 2000. EU Directive 2000/69/EC. http://eur-lex. europa.eu/.

[26] Katsoyiannis,A., Leva,P., Barrero-Moreno,J., Kotzias, D. (2012) Building materials. VOC emissions, diffusion behaviour and implications from their use. Environmental Pollution 169 (2012) 230 - 234

[27] Willem, H., Singer, B.C., (2010) Chemical Emissions of Residential Materials and Products: Review of Available Information. Environmental Energy Technologies Division 2010,page 3 - 5,20, LBNL - 3938E

[28] Jarnstrom, H., Saarela,K., Kalliokoski, P., Pasanen A.-L., (2006) Reference values for indoor air pollutant concentrations in new, residential buildings in Finland. Atmospheric Environment 40 (2006) 7178-7191

[29] Norrback, D., Bjornsson, E., Janson, C., Widstrom, J., Boman, G., (1995). Asthmatic symptoms and volatile organic compounds, formaldehyde and carbon dioxide in dwellings. Occupational and Environmental Medicine 52, 388-395.

[30] <http://www.oehha.ca.gov/prop65/pdf/june2003StatusReport.pdf>.

[31] IARC (International Agency for Research on Cancer), (2004). Monographs on the Evaluation of the Carcinogenic Risks of Chemicals to Man. WHO, Geneva

[32] Koren, H.S., Devlin, R.B., 1992. Human upper respiratory tract responses to inhaled pollutants with emphasis on nasal lavage. Ann. N.Y. Acad. Sci. 641, 215-224.

[33] Wieslander, G., Norback, D., Bjornsson, E., Jansom, C., Bomann, G., (1997). Asthma and the indoor environment: the significance of emissions of formaldehyde and volatile organic compounds from newly painted indoor surfaces. Int. Arch. Occup. Environ. Health 69, 115-124.

[34] Herbarth, O., Diez, U., Fritz, G., Rehwagen, M., Kroessner, T., Borte, M., Wetzig, H., Lehmann, I., Mueller, A., Metzner, G., Richter, M., Schulz, R., (2000). Effect of inddor chemical exposure on the development of allergies in newborn - LARS study. Proc. Healthy Build. 1, 281-286.

[35] Diez, U., Rehwagen, M., Rolle-Kampczyk, U., Wetzig, H., Schulz, R., Richter, M., Lehmann, I., Borte, M., Herbarth, O., (2003). Redecoration of apartments promotes obstructive bronchitis in atopy risk infants-results of the LARS Study. Int. J. Hyg. Environ. Health 3, 173-179.

[36] IARC, (2004). Overall evaluation of Carcinogenicity to Humans, Formaldehyde [50-00-0], Monographs Series, 88. International Agency for Research on Cancer, Lyon, France. 
[37] Jarnstrom, H., Saarela, K., Kalliokoski, P., Pasanen A-, L., (2007). Reference values for structure emissions measured on-site in new residential buildings in Finland. Atmospheric Environment 41, 2290 - 2302.

[38] Missia, D. A., Demetriou, E., Michael, N., Tolis, E.l., Bartzis J.G.,(2010) Indoor exposure from building materials: A field study. Atmospheric Environment 44 (2010) 4388 - 4395

[39] Seung, H. S., Wan K. J. (2012) Volatile organic compound concentrations, emission rates, and source apportionment in newly-built apartments at pre-occupancy stage. Chemosphere 89 (2012) 569-578

[40] Guo, H., 2011. Source apportionment of volatile organic compounds in Hong Kong homes. Build. Environ. 46, 22802286.

[41] Guo, H., So, K.L., Simpson, I.J., Barletta, B., Meinardi, S., Blake, D.R., 2007. C1-C8 volatile organic compounds in the atmosphere of Hong Kong: overview of atmospheric processing and source apportionment. Atmos. Environ. 41, 1456- 1472.

[42] Sun-Sook, K., Dong-Hwa,K., Dong-Hee, C., Myoung-Souk, Y., Kwang-Woo, K., (2008) Comparison of strategies to improve indoor air quality at the pre-occupancy stage in new apartment buildings. Building and Environment 43 (2008) 320-328

[43] Korea Ministry of Environment. Indoor Air Quality Management Act. 2003.

[44] Dr. Menyhárt Jószef: Az épületgépészet kézikönyve (1978) Múszaki könyvkiadó Budapest

[45] WHO, 2000. Air Quality Guidelines for Europe, second ed. WHO Regional Publication. European Series, No. 91.

[46] European Commission and DIRECTIVE 2000/69/EC, 2000. European Commission, DIRECTIVE 2000/69/EC of the European Parliament and of the Council of 16 November 2000 relating to limit values for benzene and carbon monoxide in ambient air. Official Journal of the European Communities 13.12.2000.

[47] Frontczak,M., Wargocki, P., (2011) Literature survey on how different factors influence human comfort in indoor environments. Building and Environment 46 (2011) 922 - 937

[48] ECA (1997) (European Collaborative Action "Indoor Air Quality and its Impact on Man"): Evaluation of VOC Emissions from Building Products - Solid Flooring Materials. Report No. 18, EUR 17334 EN, European Commission, Joint Research Centre, Environment Institute.

[49] AgBB (2012) Updated List of LCl values 2012 in Part 3, Health-related Evaluation Procedure for Volatile Organic Compounds Emissions (VOC and SVOC) from Building Products; http://www.umweltbundesamt.de/produkte-e/ bauprodukte/archive/agbb_evaluation_scheme_2012.pdf

[50] Kostiainen, R. (1995) Volatile Organic Compounds in the indoor air of normal and sick houses. Atmospheric Environ- ment Vol. 29, No. 6, pp. 693702, 1995

[51] Dr. Menyhárt Jószef: Az épületgépészet kézikönyve (1978) Múszaki könyvkiadó Budapest

[52] Young-Kyu, L., Hyun-Joong, K., (2012) The effect of temperature on VOCs and carbonyl compounds emission from wooden flooring by thermal extractor test method. Building and Environment 53 (2012) 95 - 99 